\title{
POPULATION DYNAMICS AND CONTROL OF CERTAIN PESTS INFESTING GREEN BEAN (PHASEOLUS VULGARIS) AT QALUBIYA GOVERNORATE, EGYPT
}

\author{
AMAAR, MONA I. ${ }^{1}$, S. A. EL-REFAI ${ }^{2}$, \\ RANIA S.A. RASHWAN ${ }^{2}$ and M. F. A. H. HEGAB ${ }^{1}$ \\ 1. Plant Protection Research Institute, ARC, Dokki, Giza, Egypt. \\ 2. Department of Plant Protection, Faculty of Agriculture, Ain Shams University.
}

(Manuscript received 24 March 2014)

\begin{abstract}
This investigation was carried out at Qalubiya Governorate during two successive seasons 2011 \& 2012 to study population dynamics of Bemisia tabaci (Genn.), Liriomyza trifolii (Burg.) and Tetrenchys urticae (Koch) on Green bean (Phaseolus vulgaris), and to evaluate the efficiency of five control agents (Agromec gold 1.8 EC, Actellic 50\% EC, Achook 0.15, KZ OIL 95\% E.C and KZ OIL + Match) when the population densities of these pest were high. The seasonal abundance of $B$. tabaci and $L$. trifolii were higher during second season 2012 than that recorded during the first season 2011 with mean number of 262.7 and 247.0 / 10 leaves and 196 and 159 larvae / 10 leaves, respectively. The mean number of $T$. urticae showed that the population density in the first season was higher than second season with mean number of 96.4 and 65.2 eggs/ 10 leaves and 95.4 and 65.9 movable stage), respectively. On the other hand B. tabaci, L. trifolii and T. urticae had two peaks during this period. Minimum and Maximum temperatures were showed significant negative effects on $B$. tabaci (egg and nymph) during two seasons. The relative humidity had only significant positive effect on $L$. trifolii and movable stages of $T$. urticae at the second season. Minimum and Maximum temperature had significant negative effects on egg of $T$. urticae at the second season only, The most efficient control agents after general mean of 14 days of spraying was KZ OIL + Match the mortality percentages were $78.7,81.08$ and $81.80 \%$ nymph of $B$. tabaci, larvae $L$. trifolii and movable stages $T$. urticae, respectively. on the other hand, the least potent were Agromec gold $1.8 \mathrm{EC}$ on nymph B. tabaci $50.85 \%$, Actellic $50 \% \mathrm{EC}$ on larvae L. trifolii $60.13 \%$ and Achook 0.15 on movable stages T. urticae $65.12 \%$.

Key Words: Population fluctuations, Bemisia tabaci (Genn.), Liriomyza trifolii (Burg), Tetranychus urticae (Koch), peaks, Green bean (Phaseolus vulgaris) L., Control agents, Minimum temperature, Maximum temperature, Relative humidity.
\end{abstract}

\section{INTRODUCTION}

Green bean (Phaseolus vulgaris) is one of the most popular vegetable crops in Egypt which cultivated in more than 60,000 feddan for local consumption the export purposes to West Europe (M.A.G.L.R., 2011). Egypt is considered to be the first among the countries which cultivate it. Green bean is a high nutritive food containing $6.2 \%$ protein, $0.2 \%$ fat and $63 \%$ carbohydrate with a moisture content of about $90 \%$ 
(http://world-population.net/food/ar/2170). In addition to the mature dry seed, fresh pods are often consumed as vegetable and the rest of the plants used as animal fodder. The green bean Phaseolus vulgaris $\mathrm{L}$. is liable to be attacked by several pests. Many insects belonging to the different orders, Lepidoptera, Diptera, Hemiptera, Homoptera and Thysanura as well as mit pests Tetranychidae attack green bean (Awadalla et al., 1991, Berlinger, 1986, Schuster et al., 1996, Cohen and Berlinger, 1986, Schuster and Everett, 1983, Parrella, 1987, Abd El-Gawwad, 2008, Parrella et al., 1985 and Saleh, 2011).

This study aimed to evaluate the population fluctuation of certain pests infesting green bean (Phaseolus vulgaris)., number and duration of seasonal field generations, the combined effects of principle climatic factors on pests and the efficiency of control agents on green bean pests.

\section{MATERIALS AND METHODS}

Experiments were conducted in the experimental Research Station, Qaha, Qalubiya governorate, in two successive autumn seasons 2011 and 2012. The variety "Bronco" green bean (Phaseolus vulgaris), was sown in $15^{\text {th }}$ of September and left until $5^{\text {th }}$ of december. An area of about $175 \mathrm{~m}^{2}$ approximately dividend into 4 replicates to study population dynamics of these pests. Inspection was started 18 days after sowing. Sample of 10 leaves/ replicate were collected randomly at early morning each weekly untill the harvest. Numbers of insect stages and egg \& movable stages of spider mite were counted kept in paper bag and transferred to the laboratory to examine and count the number of each investigated pest. The total numbers were registered and the mean were calculated number and duration of seasonal field generations of different pests on green bean were also calculated. To study the effect of Maximum temperature, Minimum temp. and Mean relative humidity (R.H \%) on population dynamics of these pests, the simple correlation ( $r$ ) and the partial regression (b) were calculated between each of the above mentioned factors (Xs) and the weekly mean numbers of these pests.

To study the efficacy of the tested insecticides on the population of pests infesting green bean plants, the area of this experiment was about $1200 \mathrm{~m}^{2}$, divided into 18 plots (each treatment replicated 3 times) for 5 insecticides (Table 1).Treatments of green bean var. Bronco, arranged in a randomized complete block design. A Knapsack sprayer (10 litter) was used, and filled with that prepared concentration just before each treatment. Spraying started when the infestation reached more than $5 \%$ in the plant leaves, Green bean plants was treated on $10^{\text {th }}$ 
October. Inspection of plants was carried out before spraying (zero time) and after 1, $3,5,7,10$ and 14 days after application. The mortality percentages were calculated according to the equation of Henderson and Tilton (1955).

Table 1. Insecticides used against pests on green bean plants at Qaha - Qalubiya governorate.

\begin{tabular}{|c|c|c|}
\hline Trade Name & Common Name & Rate / L Water \\
\hline Agromec gold 1.8 EC & Abamectin & $30 \mathrm{~cm}^{3} / 100 \mathrm{~L}$ \\
\hline Actellic 50\% EC & Pirimiphos methyl & $350 \mathrm{~cm}^{3} / 100 \mathrm{~L}$ \\
\hline Achook 0.15 & Azadirchtin & $750 \mathrm{~cm}^{3} / \mathrm{F}$ \\
\hline KZ OIL 95\% E.C & crude oil E.C & $1.5 \mathrm{~L} / 100 \mathrm{~L}$ \\
\hline KZ OIL + Match & crude oil E.C + Lufenuron & $1.5 \mathrm{~L} / 100 \mathrm{~L}+160 \mathrm{~cm}^{3} / \mathrm{F}$ \\
\hline
\end{tabular}

\section{RESULTS AND DISCUSSION}

\section{Population fluctuations of certain pests infesting green bean (Phaseations vulgaris L.).}

\subsection{Bemisia tabaci}

Data in Table 2, 3 revealed that the activity period of $B$. tabaci egg on autumn plantation during first season was expressed by two peaks, the lower one was $97 \mathrm{egg} /$ 10 leaves on $17^{\text {th }}$, October and the higher peak was 162 egg $/ 10$ leaves on $28^{\text {th }}$, November. In the second season, two peaks also were recorded. The lower peak was 66 egg /10 leaves on $24^{\text {th }}$, October and the higher one was 107 egg /10 leaves on $28^{\text {th }}$, November. The activity period of $B$. tabaci nymphs during first season was expressed by two peaks on $17^{\text {th }}$, October and $21^{\text {st }}$, November (182 and 191 nymph /10 leaves), respectively. The same trend was obtained during second season, the higher peak was 312 nymph /10 leaves on $28^{\text {th }}$, November and the lowest one was 213 nymph / 10 leaves on $24^{\text {th }}$, October. In general B. tabaci had two generation during this period on green bean plant.

\subsection{Liriomyza trifolii}

Data in Table 2, 3 revealed that the population of $L$. trifolii was higher during the second season than the first season, with mean number of 196 and 159 larvae / 10 leaves, respectively. In the first season, the population density recorded two peaks on $17^{\text {th }}$, October and the $14^{t}$ November with mean number of 232 and 172 larvae / 10 leaves, respectively. In the second season, the larval population density of $L$. trifolii had also two peaks, the $1^{\text {st }}$ peak on the $2^{\text {nd }}$ week of October (256 larvae/ 10 leaves) and the second one was 270 larvae/ 10 leaves on $1^{\text {st }}$ week of November. 


\subsection{Tetrenchys urticae}

Data in Table 2, 3 revealed that the activity period of $T$. urticae eggs on autumn plantation during first season had two peaks, the $1^{\text {st }}$ peak on $3^{\text {rd }}$, October (77 eggs/ 10 leaves) and the $2^{\text {nd }}$ peak on $21^{\text {st }}$, November (392 egg /10 leaves). In the second season, the population recorded also two peaks. The lower pea 98 egg /10 leaves on $7^{\text {th }}$, November and the higher peak had 113 egg $/ 10$ leaves on $5^{\text {th }}$, December. Concerning the activity period of $T$. urticae movable stage, the first season had two peaks on $3^{\text {rd }}$, October (206 nymph /10 leaves) and (211 nymph /10 leaves) on $5^{\text {th }}$, December. The same trend was obtained during second season, the lower peak had 111 individuals / 10 leaves on $24^{\text {th }}$, October and the higher one was 183 nymph / 10 leaves on $28^{\text {th }}$, November.

These results are in agreement with those obtained by EI-Sayed et al. (1991) who indicated that bean leaves showed high rate of infestation with $B$. tabaci immature stages in all plantations (early summer, summer and winter). They also mentioned that periods of high infestation rates were in August and September for summer plantation, October and November for winter plantation and July and August for the early summer plantation. Also El-Khayat et al. (1994) estimated the relative population density of $B$. tabaci stages on leaves of summer and winter vegetable crops at two locations in Qalubiya Governorate (Moshtohor and, El-Kanater ElKhaireia). In winter crops the heaviest infestation levels were detected during November, followed by December, then the rates of infestation dropped sharply during January and February, due mainly to the sharp decrease in temperature. Concerning the whole average of infestation rate, it appeared much higher on leaves of winter crops than summer ones.in addition, Abd EI-Gawwad (2004) showed that the population density of $T$. urticae was the main Tetranychidae mite infesting common bean leaves. The first appearance of this mite occurred at the first count during September. The population increased until reaching its peak during the end of October or during November. Shalaby (2004) indicated that the total L. trifolii larvae population reached its maximum on November $28^{\text {th }}$ during the first season 2002 on common bean plants. The total larvae population achieved its maximum on November $20^{\text {th }}$ during the second season 2003. The numbers of larvae and mines of $L$. trifolii were higher in the first season than the second one, however the population abundance followed the same trend at both seasons indicating that lower part of common bean plants showed higher infestation rate of Liriomyza, followed by the middle and the upper part, which harbored the least population level. Again, Abd ElGawwad (2008) indicated that the mean number of L. trifolii (larval and pupal stages) population on common bean plants reached its maximum on $1^{\text {st }}$ week of April during 
the two seasons (2005 and 2006) in the summer plantation, while during nili plantation in 2005/2006 season, it reached its maximum level on $4^{\text {th }}$ week of October and during season 2006/2007 the maximum level occurred on $2^{\text {nd }}$ week of December.

\section{II- The combined effect of some weather factors:}

\section{1 Bemisia tabaci}

Statistical analysis for the effects of the three selected weather factors on the population dynamics of $B$. tabaci eggs and nymphs during both seasons at Qalubiya Governorate are given in Table (4).These results revealed significant negative effects of minimum and maximum temperature on the seasonal fluctuations of $B$. tabaci eggs throughout both season where " $r$ " values were -0.69 and -0.66 during 2011, and were -0.82 and -0.86 during 2012 for the two factors, respectively. While the mean percentages of relative humidity had insignificant positive effect in both seasons where " $r$ " values $=0.47$ and 0.47 , respectively. The combined effect (E.V) of these ecological factors on $B$. tabaci eggs showed that these factors were responsible as a group for $58 \%$ and $78 \%$ effects on the population dynamics of B. tabaci eggs throughout both seasons, respectively.

Also the effect of these factors both minimum and maximum temperature showed significant negative effects on the seasonal fluctuations of $B$. tabaci nymphs throughout both seasons where " $r$ " values were -0.61 and -0.61 during 2011, also " $r$ " values were -0.71 and -0.77 during 2012 for the two factors, respectively. While the mean percentages of relative humidity had insignificant positive effect in both season where " $r$ " values $=0.38$ and 0.33 , respectively. The percentage of the explained variances (E.V) for three selected ecological factors during both seasons were $49 \%$ and $74 \%$ effects on the population dynamics of $B$. tabaci nymphs for the both seasons, respectively.

\subsection{Liriomyza trifolii}

Statistical analysis for the effects of the three selected weather factors on the population dynamics of $L$. trifolii during 2011 and 2012 seasons were given in Table (4). These results revealed that minimum and maximum temperature had insignificant positive effects on seasonal fluctuation of larvae during first season 2011 where " $r$ " values were 0.13 and 0.21 , respectively. While in second season the minimum temperature had insignificant positive effects (" $r$ " value was 0.04 ) but maximum temperature had insignificant negative effects (" $r$ " value was -0.28). The mean percentage of relative humidity had insignificant negative effects where, " $r$ " value was -0.31 in first season but in second season had significant positive effects on seasonal fluctuation of larvae where " $r$ " value was 0.66 . The percentage of explained variances (E.V) for the three selected ecological factors during both seasons were $22 \%$ and 51 
$\%$ effects on the population dynamics of larvae of $L$. trifolii for the both seasons, respectively.

\subsection{Tetrenchys urticae}

Statistical analysis for the effects of the three selected weather factors on the population dynamics of T. urticae during 2011 and 2012 seasons were given in Table (4). These results revealed that minimum, maximum temp. had insignificant negative effects on seasonal fluctuation of $T$. urticae egg where " $r$ " value were $-0.51,-0.55$ during 2011, but in the second season showed significant negative effects where " $r$ " value were -0.66 and -0.74 for the two factors, respectively. While the mean percentages of relative humidity had insignificant positive effect in both seasons where " $r$ " values $=0.35$ and 0.53 , respectively. The combined effect (E.V) of these ecological factors on $T$. urticae eggs showed that these factors were responsible as a group for $36 \%$ and $57 \%$ effects on the population dynamics of $T$. urticae eggs throughout both seasons, respectively.

Also the effect of these factors both minimum and maximum temperature showed insignificant negative effects on the seasonal fluctuations of $T$. urticae movable stage in the first season where " $r$ " values were -0.44 and -0.50 during 2011 , but in the second season showed insignificant negative effects of minimum temp. Factor (" $r$ " values was -0.50) but maximum temperature had significant negative effect (" $r$ " values was -0.66 ). While the mean percentages of relative humidity had significant positive effect in first season where " $r$ " values $=0.63$ and the second season showed insignificant positive " $r$ " values $=0.43$. The percentage of explained variances (E.V) for the three selected ecological factors during the both seasons were $49 \%$ and $52 \%$ effects on the population dynamics of $T$. urticae nymphs for the both seasons, respectively.

These results are in agreement with those obtained by Younes et al. (2001) who detectedsignificant negative correlation between the tested weather factors. Saradhi and Patnaik (2004) mentioned that Correlation studies of the serpentine, L. trifolii revealed that diurnal temperature variation was negatively correlated. Jesus et al. (2009) observed a negative and non significant linear correlation between average temperatures of whitefly number.

\section{3- The efficiency of control agents on green bean pests:}

\section{1 Bemisia tabaci}

Comparing the mean reduction percentages in population of $B$. tabaci nymph after applications of five compounds it is clear that the five control agents can be arranged in descending orders as follows: KZ OIL + Match, Actellic 50\%EC, KZ OIL 
95\% EC, Achook 0.15 and Agromec gold $1.8 \mathrm{EC}$, with mean reduction of 78.70, 77.83, $71.53,65.48$ and 50.85 .for the five agents, respectively. (Table 5)

According to the mean, percentage of reduction in $B$. tabaci counts after treatment, the compounds significantly into could be divided four groups $(F$. value $=$ 13.39 and L.S.D $=9.19 \%$.

\subsection{Liriomyza trifolii}

According to mean percentage of reduction in population of $L$. trifolii larvae, it is clears that the $\mathrm{KZ} \mathrm{OIL}+$ Match was the most potent one as mean of reduction was $81.08 \%$ followed by KZ OIL 95\% EC (73.06\%), Achook 0.15 (69.76\%), Agromec gold $1.8 \mathrm{EC}(69.53 \%)$ and the least potent one was Actellic 50\%EC (60.13\%).was the least potent one. (Table 6)

The tested compounds could be significantly divided into four groups. According to the percentage of reduction in L. trifolii larvae (F. value $=7.65$ and L.S.D $=8.04 \%$ ).

\subsection{Tetrenchys urticae}

According to the percentage of reduction in T. urticae data in Table 7 indicated significant differences between the five compounds where $\mathrm{F}$. value $=10.52$ and L.S.D $=8.33 \%$. These compounds could be divided two groups. The first group contained on Agromec gold 1.8 EC, KZ OIL + Match and KZ OIL 95\% EC showing highly mortality $86.39,81.80$ and $80.33 \%$, respectively. The second group contained on Actellic 50\%EC and Achook 0.15 showing moderate effect 68.39 and $65.12 \%$, respectively. (Table 7)

These results are in agreement with those obtained by Omar and Faris (2000) who found that, Reldan was the most effective one in controlling leaf miner population and resulting in the highest quality and quantity of green yield of $P$. vulgaris followed by vertemic and Neemazal compounds. Soliman et al. (2007) indicated that mixture of vertimec and super-misrona mineral oil exhibited the highest reduction $(91.4 \%)$ followed by vertimec $(87.5 \%)$, mineral oil $(72.9 \%)$, on spider mites population. Abbassy et al. (2009) mentioned that Super Misrona oil gave 71.73 percent of reduction of infestation against the adult stages of $\mathrm{T}$. urticae. 
Table 2. Weekly mean numbers of pests and certain ecological factors on green bean var. Bronco at Qalubiya Governorate during autumn season 2011.

\begin{tabular}{|c|c|c|c|c|c|c|c|c|}
\hline \multirow{2}{*}{ [RH\%] } & \multicolumn{2}{|c|}{ Temp. } & \multicolumn{2}{|c|}{ T. urticae } & \multirow{2}{*}{ L. trifolii } & \multicolumn{2}{|c|}{ B. tabaci } & \multirow{2}{*}{ Date } \\
\hline & Min & Max & immature & egg & & nymph & egg & \\
\hline 71.3 & 17.5 & 24.3 & 206 & 77 & 136 & 144 & 27 & $03 / 10$ \\
\hline 72.0 & 15.5 & 23.0 & 19 & 12 & 139 & 149 & 33 & $10 / 10$ \\
\hline 65.9 & 15.8 & 24.3 & 0 & 0 & 232 & 182 & 97 & $17 / 10$ \\
\hline 70.4 & 15.2 & 21.3 & 0 & 0 & 164 & 171 & 40 & $24 / 10$ \\
\hline 76.4 & 13.2 & 19.6 & 37 & 16 & 143 & 177 & 36 & $31 / 10$ \\
\hline 73.6 & 10.8 & 17.6 & 12 & 77 & 135 & 136 & 55 & $07 / 11$ \\
\hline 81.0 & 9.5 & 16.7 & 103 & 199 & 172 & 183 & 112 & $14 / 11$ \\
\hline 76.1 & 10.2 & 15.3 & 177 & 392 & 166 & 191 & 161 & $21 / 11$ \\
\hline 81.6 & 8.6 & 14.3 & 189 & 118 & 129 & 162 & 162 & $28 / 11$ \\
\hline 86.6 & 7.8 & 13.6 & 211 & 73 & 169 & 156 & 96 & $05 / 12$ \\
\hline 754.85 & 124.03 & 190.1 & 954 & 964 & 1585 & 1651 & 819 & Total \\
\hline 75.48 & 12.40 & 19.01 & 95 & 96.4 & 159 & 165.1 & 81.9 & Mean \\
\hline
\end{tabular}

Table 3. Weekly mean numbers of pests and certain ecological factors on green bean var. Bronco at Qalubiya Governorate during autumn season 2012.

\begin{tabular}{|c|c|c|c|c|c|c|c|c|}
\hline \multirow{2}{*}{ [RH\%] } & \multicolumn{2}{|c|}{ Temp. } & \multicolumn{2}{|c|}{ T. urticae } & \multirow{2}{*}{ L. trifolii } & \multicolumn{2}{|c|}{ B. tabaci } & \multirow{2}{*}{ Date } \\
\hline & Min & Max & immature & egg & & nymph & egg & \\
\hline 70.71 & 32.51 & 16.47 & 0 & 0 & 150 & 110 & 19 & $03 / 10$ \\
\hline 72.71 & 31.35 & 16.62 & 0 & 0 & 256 & 196 & 33 & $10 / 10$ \\
\hline 72.57 & 31.35 & 17.74 & 0 & 0 & 180 & 189 & 32 & $17 / 10$ \\
\hline 77.86 & 31.28 & 17.92 & 111 & 90 & 180 & 213 & 66 & $24 / 10$ \\
\hline 75.43 & 28.62 & 13.96 & 98 & 88 & 214 & 199 & 53 & $31 / 10$ \\
\hline 86.71 & 28.63 & 17.49 & 50 & 98 & 270 & 127 & 34 & $07 / 11$ \\
\hline 86.00 & 27.65 & 15.30 & 23 & 15 & 178 & 199 & 50 & $14 / 11$ \\
\hline 79.00 & 25.89 & 10.63 & 154 & 109 & 187 & 262 & 81 & $21 / 11$ \\
\hline 85.57 & 23.28 & 11.43 & 183 & 119 & 175 & 312 & 107 & $28 / 11$ \\
\hline 79.57 & 25.34 & 8.93 & 40 & 133 & 173 & 248 & 97 & $05 / 12$ \\
\hline 786.14 & 285.9 & 146.49 & 659 & 652 & 1963 & 2055 & 572 & Total \\
\hline 78.61 & 28.59 & 14.64 & 65.9 & 65.2 & 196 & 205.5 & 57.2 & Mean \\
\hline
\end{tabular}


Table 4. Simple correlation and partial regression values of the three main weather factors on some pests and corresponding percentages of explained variance on autumn green bean plants at Qalubiya Governorate during 2011 and 2012 season.

\begin{tabular}{|c|c|c|c|c|c|c|c|c|c|c|c|}
\hline \multicolumn{5}{|c|}{2012} & \multicolumn{5}{|c|}{2011} & \multirow{3}{*}{ Variables } & \multirow{3}{*}{$\begin{array}{l}\text { Pests } \\
\text { stage }\end{array}$} \\
\hline \multirow[t]{2}{*}{ E.V\% } & \multicolumn{2}{|c|}{$\begin{array}{l}\text { Regression } \\
\text { coefficient }\end{array}$} & \multicolumn{2}{|c|}{ Correlation } & \multirow[t]{2}{*}{ E.V\% } & \multicolumn{2}{|c|}{$\begin{array}{l}\text { Regression } \\
\text { coefficient }\end{array}$} & \multicolumn{2}{|c|}{ Correlation } & & \\
\hline & $\mathrm{P}$ & $b$ & $\mathrm{p}$ & $r$ & & $\mathrm{p}$ & $b$ & $\mathrm{p}$ & $r$ & & \\
\hline \multirow{3}{*}{$78 \%$} & 0.87 & -0.91 & 0.003 & $\begin{array}{c}- \\
0.82\end{array}$ & \multirow{3}{*}{$58 \%$} & 0.02 & $\begin{array}{c}- \\
10.47\end{array}$ & 0.02 & $\begin{array}{c}- \\
0.69\end{array}$ & $\begin{array}{l}\text { Min. } \\
\text { temp. }\end{array}$ & \multirow{3}{*}{$\begin{array}{c}\text { B.tabaci } \\
\text { ( Egg) }\end{array}$} \\
\hline & 0.31 & -0.87 & 0001 & $\begin{array}{c}- \\
0.86\end{array}$ & & 0.03 & -7.88 & 0.03 & $\begin{array}{c}- \\
0.66\end{array}$ & $\begin{array}{l}\text { Max. } \\
\text { temp. }\end{array}$ & \\
\hline & 0.70 & -0.94 & 0.16 & 0.47 & & .897 & 0.13 & 0.17 & 0.47 & $\mathrm{RH} \%$ & \\
\hline \multirow{3}{*}{$74 \%$} & 0.31 & 13.95 & 0.02 & $\begin{array}{c}- \\
0.71\end{array}$ & \multirow{3}{*}{$49 \%$} & 0.05 & $\begin{array}{c}- \\
11.24\end{array}$ & 0.05 & $\begin{array}{c}- \\
0.61\end{array}$ & $\begin{array}{l}\text { Min. } \\
\text { temp. }\end{array}$ & \multirow{3}{*}{$\begin{array}{l}\text { B.tabaci } \\
\text { (Nymph) }\end{array}$} \\
\hline & 0.07 & $\begin{array}{c}- \\
39.60\end{array}$ & 0.008 & $\begin{array}{c}- \\
0.77\end{array}$ & & 0.05 & -8.72 & 0.05 & $\begin{array}{c}- \\
0.60\end{array}$ & $\begin{array}{l}\text { Max. } \\
\text { temp. }\end{array}$ & \\
\hline & 0.13 & -8.94 & 0.35 & 0.33 & & 0.2 & 3.93 & 0.27 & 0.38 & $\mathrm{RH} \%$ & \\
\hline \multirow{3}{*}{$51 \%$} & 0.94 & -0.41 & 0.89 & 0.04 & \multirow{3}{*}{$22 \%$} & 0.71 & 1.15 & 0.71 & 0.13 & $\begin{array}{l}\text { Min. } \\
\text { temp. }\end{array}$ & \multirow{3}{*}{$\begin{array}{c}\text { liriomyza } \\
\text { trafolii } \\
\text { (larva) }\end{array}$} \\
\hline & 0.73 & 2.71 & 0.4 & $\begin{array}{c}- \\
0.28\end{array}$ & & 0.54 & 1.53 & 0.54 & 0.21 & $\begin{array}{l}\text { Max. } \\
\text { temp. }\end{array}$ & \\
\hline & 0.22 & 3.01 & 0.03 & 0.66 & & 0.38 & -1.52 & 0.38 & $\begin{array}{c}- \\
0.31\end{array}$ & $\mathrm{RH} \%$ & \\
\hline \multirow{3}{*}{$57 \%$} & 0.61 & -7.91 & 0.03 & $\begin{array}{c}- \\
0.66\end{array}$ & \multirow{3}{*}{$36 \%$} & 0.13 & $\begin{array}{c}- \\
17.87\end{array}$ & 0.13 & $\begin{array}{c}- \\
0.51\end{array}$ & $\begin{array}{l}\text { Min. } \\
\text { temp. }\end{array}$ & \multirow{3}{*}{$\begin{array}{c}\text { Tetrenchys } \\
\text { urticae } \\
\text { (Egg) }\end{array}$} \\
\hline & 0.92 & -2.14 & 0.01 & $\begin{array}{c}- \\
0.74\end{array}$ & & 0.09 & $\begin{array}{c}- \\
15.48\end{array}$ & 0.09 & $\begin{array}{c}- \\
0.55\end{array}$ & $\begin{array}{l}\text { Max. } \\
\text { temp. }\end{array}$ & \\
\hline & 0.64 & 2.99 & 0.11 & 0.53 & & 0.31 & 6.90 & 0.31 & 0.35 & $\mathrm{RH} \%$ & \\
\hline \multirow{3}{*}{$52 \%$} & 0.37 & 18.36 & 0.14 & $\begin{array}{c}- \\
0.50\end{array}$ & \multirow{3}{*}{49} & 0.19 & $\begin{array}{c}- \\
11.82\end{array}$ & 0.19 & $\begin{array}{c}- \\
0.44\end{array}$ & $\begin{array}{l}\text { Min. } \\
\text { temp. }\end{array}$ & \multirow{3}{*}{$\begin{array}{c}\text { Tetrenchys } \\
\text { urticae } \\
\text { (movable } \\
\text { stages) }\end{array}$} \\
\hline & 0.19 & -4.37 & 0.03 & $\begin{array}{c}- \\
0.66\end{array}$ & & 0.13 & $\begin{array}{c}- \\
10.70\end{array}$ & 0.13 & $\begin{array}{c}- \\
0.50\end{array}$ & $\begin{array}{l}\text { Max. } \\
\text { temp. }\end{array}$ & \\
\hline & 0.41 & -6.96 & 0.20 & 0.43 & & 0.04 & 9.47 & 0.04 & 0.63 & $\mathrm{RH} \%$ & \\
\hline
\end{tabular}


Table 5. efficiency of five control-agents against B. tabaci nymphs on green bean plants at Qalubiya Governorate on autumn 2012.

\begin{tabular}{|c|c|c|c|c|c|c|c|c|}
\hline \multirow{2}{*}{$\begin{array}{c}\text { Average } \\
\%\end{array}$} & \multicolumn{5}{|c|}{ Residual effect treatments } & \multirow{2}{*}{$\begin{array}{c}\begin{array}{c}\text { Initial } \\
\text { Kill }\end{array} \\
\begin{array}{c}\text { After } 24 \\
\text { hours }\end{array}\end{array}$} & \multirow{2}{*}{$\begin{array}{c}\text { No. } \\
\text { larvae } \\
\text { Per } \\
\text { Treatments }\end{array}$} & \multirow{2}{*}{ Treatments } \\
\hline & $\begin{array}{c}14 \\
\text { Days }\end{array}$ & $\begin{array}{c}10 \\
\text { Days }\end{array}$ & $\begin{array}{c}7 \\
\text { Days }\end{array}$ & $\begin{array}{c}5 \\
\text { Days }\end{array}$ & $\begin{array}{c}3 \\
\text { Days }\end{array}$ & & & \\
\hline $50.850 c$ & 78.4 & 65.7 & 36.6 & 45.8 & 45.7 & 32.9 & 278 & $\begin{array}{c}\text { Agromec gold } 1.8 \\
\text { EC } \\
\end{array}$ \\
\hline $77.833 a$ & 100.0 & 96.0 & 87.7 & 86.3 & 61.7 & 35.3 & 150 & Actellic 50\% EC \\
\hline $65.483 \mathrm{~b}$ & 90.4 & 73.0 & 66.5 & 62.5 & 52.1 & 48.4 & 110 & Achook 0.15 \\
\hline $71.533 a b$ & 93.0 & 88.3 & 76.5 & 67.3 & 56.6 & 47.5 & 90 & KZ OIL 95\% E.C \\
\hline 78.700a & 98.6 & 92.8 & 72.4 & 80.0 & 76.3 & 52.1 & 100 & KZ OIL + Match \\
\hline-- & -- & -- & -- & -- & -- & -- & 116 & Control \\
\hline
\end{tabular}

Table 6. efficiency of five control-agents against $L$. trifolii larvae on green bean plants at Qalubiya Governorate on autumn 2012.
$\mathrm{F}=7.65$
L.S.D. $=8.04 \%$

\begin{tabular}{|c|c|c|c|c|c|c|c|c|}
\hline \multirow{2}{*}{$\begin{array}{c}\text { Average } \\
\%\end{array}$} & \multicolumn{5}{|c|}{ Residual effect treatments } & \multirow{2}{*}{$\begin{array}{c}\text { Initial } \\
\text { Kill } \\
\text { After } \\
24 \\
\text { hours } \\
\end{array}$} & \multirow{2}{*}{$\begin{array}{c}\text { No. } \\
\text { larvae } \\
\text { Per } \\
\text { Treatments }\end{array}$} & \multirow[b]{2}{*}{ Treatments } \\
\hline & $\begin{array}{c}14 \\
\text { Days }\end{array}$ & $\begin{array}{c}10 \\
\text { Days }\end{array}$ & $\begin{array}{c}7 \\
\text { Days }\end{array}$ & $\begin{array}{c}5 \\
\text { Days }\end{array}$ & $\begin{array}{c}3 \\
\text { Days }\end{array}$ & & & \\
\hline $69.533 b$ & 85.0 & 82.8 & 76.7 & 59.5 & 54.6 & 58.6 & 113 & $\begin{array}{c}\text { Agromec gold } \\
1.8 \mathrm{EC}\end{array}$ \\
\hline $60.133 c$ & 57.6 & 79.2 & 72.9 & 59.2 & 47.7 & 44.2 & 108 & $\begin{array}{c}\text { Actellic } 50 \% \\
\text { EC }\end{array}$ \\
\hline $69.767 \mathrm{~b}$ & 74.3 & 77.4 & 73.0 & 70.1 & 66.9 & 56.9 & 119 & Achook 0.15 \\
\hline 73.067ab & 93.1 & 90.9 & 83.8 & 67.4 & 55.0 & 48.2 & 99 & $\begin{array}{c}\text { KZ OIL } 95 \% \\
\text { E.C } \\
\end{array}$ \\
\hline $81.083 a$ & 100.0 & 100.0 & 85.7 & 72.4 & 65.2 & 63.2 & 123 & $\begin{array}{c}\text { KZ OIL + } \\
\text { Match }\end{array}$ \\
\hline-- & -- & -- & -- & -- & -- & -- & 190 & Control \\
\hline
\end{tabular}


Table 7. efficiency of five control-agents against $T$. urticae movable stage on green bean plants at Qalubiya Governorate on autumn 2012.

\begin{tabular}{|c|c|c|c|c|c|c|c|c|}
\hline \multirow{2}{*}{$\begin{array}{c}\text { Average } \\
\qquad \%\end{array}$} & \multicolumn{5}{|c|}{ Residual effect treatments } & \multirow{2}{*}{$\begin{array}{c}\text { Initial Kill } \\
\text { After } 24 \\
\text { hours }\end{array}$} & \multirow{2}{*}{$\begin{array}{c}\text { No. } \\
\text { larvae } \\
\text { Per } \\
\text { Treatments }\end{array}$} & \multirow[b]{2}{*}{ Treatments } \\
\hline & $\begin{array}{c}14 \\
\text { Days }\end{array}$ & $\begin{array}{c}10 \\
\text { Days }\end{array}$ & $\begin{array}{c}7 \\
\text { Days }\end{array}$ & $\begin{array}{c}5 \\
\text { Days }\end{array}$ & $\begin{array}{c}3 \\
\text { Days }\end{array}$ & & & \\
\hline $86.392 a$ & 97.5 & 96.5 & 94.2 & 87.8 & 73.1 & 69.3 & 272 & $\begin{array}{c}\text { Agromec gold } 1.8 \\
\text { EC }\end{array}$ \\
\hline $68.393 b$ & 86.7 & 89.5 & 68.4 & 62.4 & 51.4 & 51.8 & 260 & Actellic 50\% EC \\
\hline $65.123 b$ & 78.9 & 82.4 & 75.3 & 70.9 & 57.6 & 25.6 & 262 & Achook 0.15 \\
\hline $80.326 a$ & 96.8 & 82.8 & 80.5 & 87.7 & 72.8 & 61.4 & 269 & KZ OIL 95\% E.C \\
\hline $81.802 \mathrm{a}$ & 96.0 & 91.6 & 86.5 & 77.4 & 71.7 & 67.6 & 259 & $\mathrm{KZ}$ OIL + Match \\
\hline-- & -- & -- & -- & -- & -- & -- & 250 & control \\
\hline
\end{tabular}

\section{REFERENCES}

1. Abbassey, M. A., S. A. Mostafa, M. A. Mostafa, A.H. Mangound and S. A. Osman. 2009. Evaluation of certain chemicals and biochemical compounds on red spider mite, Tetranychus urticae Koch (Acarina: Tetranychidae) infesting cotton plants, Egypt. J. Agric. Res., 87 (1): 61-70.

2. Abd El-Gawwad, S.A.Y. 2004. Biological, ecological and biocontrol studies on some mites. Ms. Thesis Fac. of Sci. AL-Azhar, Univ. 197 pp.

3. Abd El-Gawwad, S. A.Y. 2008. Study of integrated pest management on some pests of common bean plant. Ph.D. Thesis, Zoology Department, Faculty of Science for Girls, Al-Azhar Univ., 409 pp.

4. Awadalla, S. S., A. A. El-Znan and R. M. Salem. 1991. Studies injurious insects infesting soygreen bean plants and the efficiency of certain chemicals against these pests at Kafr El-Sheikh, Egypt. J. Agric. Mansoura Univ., 16 (2): 420-429.

5. Berlinger, M.J. 1986. Host plant resistance to Bemisia tabaci. Agric. Ecosystems Environ., 17:69-82.

6. Cohen, S. and M.J. Berlinger. 1986. Transmission and cultural control of whiteflyborne viruses. Agric. Ecosystems Environ., 17:89-97.

7. El-Khayat, E. F., A.M. El-Sayed, F.F. Shalaby and S.A. Hady. 1994. Infestation rates with Bemisia tabaci (Genn.) to different summer and winter vegetable crop plants. Ann. Agric. Sci., Moshtohor, 32(1): 577-594.

8. El-Sayed, A. M., F. F. Shalaby and A. A. Abdel-Gawad. 1991. Ecological studies on Bemisia tabaci (Genn.) (HemipteraHomoptera: Aleyrodidae). Infesting different 
host plants. 1-Fluctuation and population density of Bemisia tabaci on different host plants. Egypt J. Agric. Res., 69(1): 193-207.

9. Henderson, C.F. and W.A. Tilton (1955): Test with acaricides against the wheat mite. J. Econ. Ent. 49: 157-161.

10. Jesus, F. G., A. L. Boica Junior , S. A. M. Carbonel , C. P. Stein and R. M. Pitta. 2009. Infestation of Bemisia tabaci (Genn.) biotype B (Hemiptera: Aleyrodidae) and Caliothrips phaseoli(Hood.) (Thysanoptera: Thripidae) in beans genotypes. Arquivos do Instituto Biologico (Sao Paulo). 76 (3): 393-399.

11. M. A. G. L. R. 2011. Study of important indicators of agricultural statistics. Affair sector, Central Administration Agric. Econ.,1, Pages: 95, 96, 229 and 232.

12. Omar, B. A. and F. S. Faris. 2000. Bio-residual activity of different insecticides on the beanflys and yield components of snap bean Phaseolus vulgaris (L.). Egypt J. Agric. Res., 78 (4): 1485-1496.

13. Parrella, M.P. 1987. Biology of Liriomyza. Seasonal Rev. Entomol., 32: 201-224.

14. Parrella, M.P., V.P. Jones, R.R. Youngman and L.M. Lebeck. 1985. Effect of leaf mining and leaf stippling of Liriomyza spp. on photosynthetic rates of chrysanthemum. Ann. Entomol. Soci. America, 78: 90-93,

15. Saleh, F. M. 2011. Effect of certain agricultural practices and biological control on soygreen bean pests. Ph.D. Thesis, Economic Entomol. Department, Faculty of Agric., Mansoura Univ., 219 pp.

16. Saradahi, P.P. and N. C. Pantaik. 2004. Seasonal population fluctuations of serpentine leaf miner, Liriomyza trifolii (Burgess) in different host plants. App. Zool. Res., 15 (1): 60-63.

17. Shalaby, S. H. 2004. Studies on the efficiency of some new pest control measures against certain pests of common bean. Ph. D. thesis, Fac. Agric. Moshtohor, Zagazig Univ., 265 pp.

18. Schuster, D.J., and P.H. Everett. 1983. Response of Liriomyza trifolii (Diptera: Agromyzidae) to insecticides on tomato. Econ. Entomol., 76: 1170-1174.

19. Schuster, D.J., P.A. Stansly and J.E. Polston. 1996. Expressions of plant damage of Bemisia. In D. Gerling \& R. T. Mayer (eds.). Bemisia 1995. Taxonomy, boil., damage, control and management Intercept, Uk.

20. Soliman, M. S., M. A. El-Sanady and M. A. Abdel-Aziz. 2007. Alternative safely methods in suppressing the population of two spotted spider mite, Tetranychus urticae Koch infesting soybean plants at the new reclaimed lands, Nubaria province, Egypt. J. Agric. Sci. Mansoura Univ., 32 (12): 10417-10424.

21. Younes, A. A., S. M. Soliman and S. E. Saadoon. 2001. Ecological studies on some sucking insects and mite associated with certain soygreen bean cultivars. J. Agric. Sci. Mansoura Univ., 26: 4551-4558. 


\section{ديناميكية التعداد ومكافحة بعض الآقات التى تصيب الفاصوليا

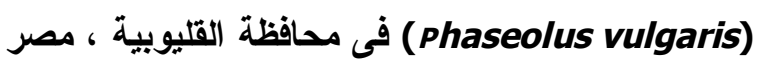

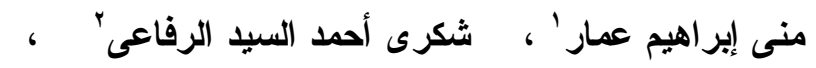

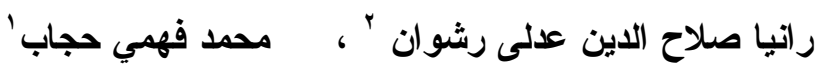

ا ـ قسم بحوث أفات الخضر والنباتات الطبية و العطرية و الزينة - معهد بحوث وقاية النباتات -

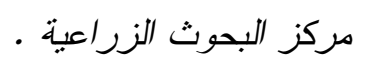

r • قسم وقاية النبات - كلية الزراعة - جامعة عين شمس الزع .

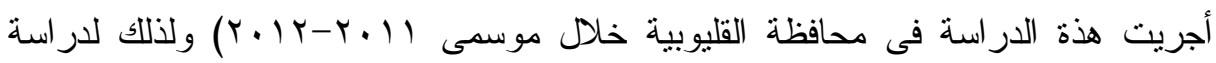

تقلبات التعداد لكل من الذبابة البيضاء- صانعات الانفاق - العنكبوت الاحمر على الفاصوليا وتم

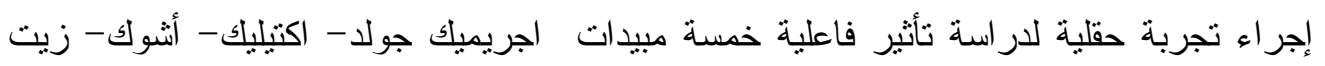

معدنى - وخلط زيت معدنى + مانش و ذللك عندما كانت تعداد هذة الآفات عالى.

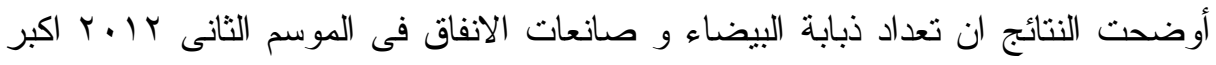

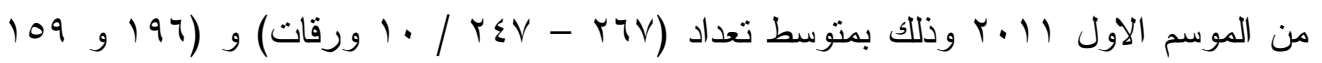

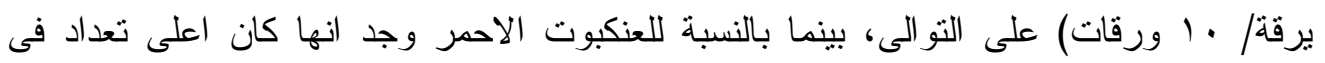

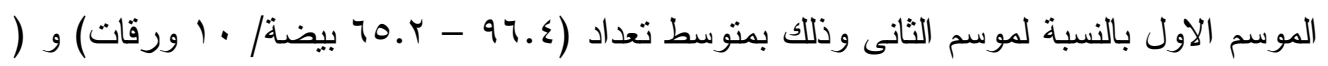

ـ.90 - 9.9 اكاروس / • ( ورقات) على التوالى، وبجانب ذلك سجلت كل من الذبابة البيضاء

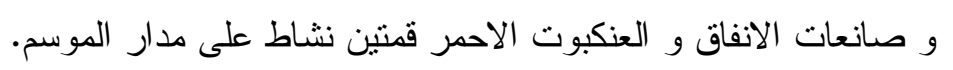

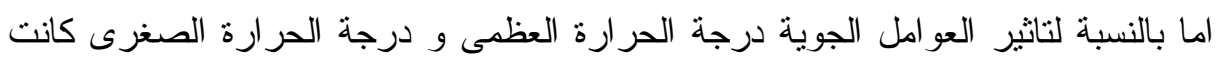
العلاقة معنوية سالبة وذلك مع الذبابة البيضاء ( بيض- حوريات) خلال الموسمين، اما بالنسبة دوانه

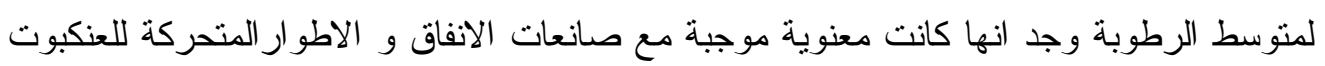

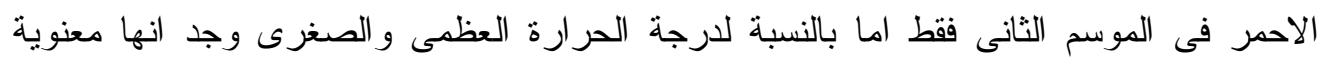
سالبة مع بيض العنكبوت الاحمر وذلك فى الموسم الثانى فقط. وبالنسبة لتقييم كفاءة الخمسة مركبات تحت الدراسة على نبات الفاصوليا كانت اعلى تاثير

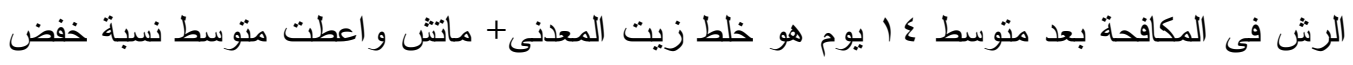

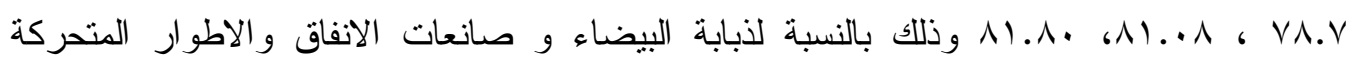

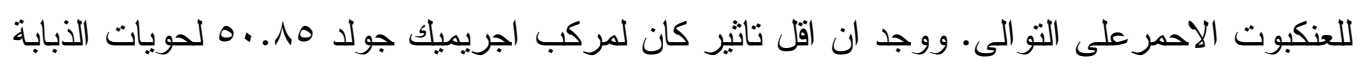

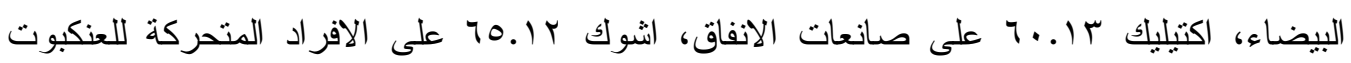

